\title{
The Case Governed by the Preposition na in Byelorussian
}

\author{
BY
}

P J MAYO

\begin{abstract}
Already in the Common Slavonic period the polysemantic preposition po, of uncertain etymology, ${ }^{1}$ was capable of combining with three cases: accusative, dative and locative (prepositional). Its distribution among these three cases according to meaning is not, however, reflected uniformly in the individual modern Slavonic languages; in particular this applies to the distribution of meanings between the constructions ' $p o+$ dative' and 'po + locative'. While the combination of po with the accusative case to convey purposive meaning ('for' = 'to fetch, get'), spatial limit ('up to') and, to a lesser extent, distributive meaning ('each') is widespread and generally uniform, in other meanings (spatial, temporal, objective, causative etc.) there is variation both as to the particular meanings within those categories that the preposition can convey and as to the case with which it is combined in doing so.
\end{abstract}

Part of the reason for the latter may well lie in the historical origins of the dative and locative cases. V.N. Toporov, in his study of the locative in the Slavonic languages, takes issue with the still predominantly accepted theory that the locative case originated in Indo-European, was inherited by the languages which developed therefrom, but was subsequently (though still in prehistoric times) lost by some of them (e.g. the Celtic and Germanic languages). Toporov's view is that the evidence of Hittite, Greek, Latin and the Mesopotamian languages points rather in the direction of the original non-differentiation of dative and locative, and the development of a separate locative case, most probably of adverbial origin, at a later stage in the history of some languages or language-groups from the eastern part of Indo-European territory. ${ }^{2}$

Whether or not Toporov is correct in this view, historical and dialectological evidence certainly points to the construction ' $p o+$ dative' as generally predating 'po + locative' in the Slavonic languages. Thus in the earliest texts in Old Church Slavonic, Russian, Ukrainian, Byelorussian, Polish, Bulgarian and Serbo-Croat the dative case is the norm for most constructions with the preposition po; only in the spatial and temporal meaning of 'after' can the combination of po with the locative be reasonably postulated for the Common Slavonic period. ${ }^{3}$

Since the early historical period, however, there has been a general shift from ' $p o$ + dative' to 'po + locative' so that in modern times it is the latter construction which predominates (except in Russian, where the reverse is true). Thus in the West Slavonic languages as a whole the construction ' $p o+$ dative' is confined to a few fixed expressions in Lusatian and with the meaning 'according to' to a limited number of 
adverbial expressions in Czech. In the South Slavonic languages the question of 'po + dative' versus 'po + locative' does not arise in Bulgarian or Macedonian, since they do not have a case system, nor in SerboCroat which does not formally distinguish dative and locative. Slovene, like Serbo-Croat, does not formally distinguish dative and locative in the singular, and though it does so in the dual and plural po, when not combined with the accusative case, is found only with the locative. It is thus chiefly in the East Slavonic languages that competition between the two constructions is to be encountered.

Even within the East Slavonic languages, however, the differentiation comes down essentially to one between Russian and Byelorussian; in Ukrainian the use of 'no + dative', though still the norm as late as the 16 th-17th centuries (as indeed it was in Byelorussian), ${ }^{4}$ is restricted in the modern standard language to adverbial combinations of the type по-моємy etc. In modern Russian, alone among the Slavonic languages, the construction 'nо + dative' has all but ousted 'no + locative' and is showing distinct signs of aggression towards other syntactic constructions, both prepositional and prepositionless. ${ }^{5}$ As Toporov points out:

In general the loc. with the preposition no received little development in the system of the Russian locative and over the course of 8-9 centuries has significantly contracted the limits of its spread; moreover, in the literary language in not one of its meanings is the loc. with the preposition no the sole or even the basic means of expressing this or that relationship. ${ }^{6}$

Indeed, so rare has the construction 'no + locative' become, in standard Russian at least, that the author of a recent monograph on prepositions in modern Russian does not even see fit to mention the existence of such a construction. ${ }^{7}$

Writing a quarter of a century ago V.S. Bondarenko, while mentioning the use of the construction 'no + locative' after such verbs of feeling as скучать, тосковать, вздьхать, грустить, страдать, горевать etc., notes that already it was being referred to in grammars and textbooks as archaic or dialectal, with preference being given to 'no + dative' or, as an alternative, 'o + locative'. ${ }^{8}$ The only meaning with which 'no + locative' is regarded by Bondarenko as standard is that of 'after' in such expressions as по окончании, по приезде, по уходе etc., though even this usage is generally limited to the scientific, technical and administrative styles of language. ${ }^{9}$ In combination with the personal pronouns, however, no was consistently used with the locative case even for meanings which were conveyed by 'nо + dative' where a noun was involved. ${ }^{10}$ In a statistical analysis of grammatical usage published in 1976, L.K. Graudina et al. confirm the picture painted by Bondarenko and show furthermore that even where personal pronouns are concerned 'nо + dative' is now overwhelmingly the norm (по немy $91.66 \%$ : по нем $8.34 \%$ ), only мы and вы appearing regularly in the locative case after no in modern Russian. ${ }^{11}$.

In Byelorussian, by contrast, apart from those meanings in which it 
is combined with the accusative case, па is used predominantly with the locative, indeed in the plural exclusively so. If the evidence with regard to the plural is incontrovertible, that concerning the singular is much less clear-cut. Untangling it is not made any easier by the (not wholly unjustified) suspicion on the part of some Byelorussians that the use of the dative can be put down to Russification, nor by the frequent coincidence of form between dative and locative, nor yet by the sometimes conflicting recommendations that appear in some textbooks and other scholarly writings on the subject. ${ }^{12}$

In this article we shall examine agreement with the preposition па in modern Byelorussian under various semantic headings (spatial meaning, temporal, objective, etc). The data are provided by a number of works of literature which span the period of the modern literary language. They are, with abbreviations of the authors' names in brackets:

Michaś Zarecki, Ściězki-darožki, published 1927 (MZ);

Kuźma Corny, Treciaje pakaleńnie, published 1935, and Luba Łuk'janskaja, published 1936 (KČ);

Ivan Mielež, Ludzi na batocie, published 1960 (IM);

Viačasłaǔ Adamčyk, Čužaja baćkaŭščyna, published 1978 (VA).

The corpus of material by each author is of approximately the same length (c. 360 pages).

As was mentioned above, quite apart from the fact that in the plural the preposition па is never combined with the dative case in Byelorussian, ${ }^{13}$ there are many instances in the singular in which dative and locative are not formally distinguished. This is true of all nouns belonging to the first and third declensions, as well as certain categories of masculine and neuter nouns of the second declension which take the ending $-\mathrm{y}(-\mathrm{-})$ in the locative case (all those with a stem ending in a $\mathrm{K}$; those with a stem ending in $ж, ч, w, L, p$ or a soft consonant which denote human beings) ${ }^{14}$ and, among pronouns, я, ты, яна and the reflexive pronoun. In the case of second declension nouns (and masculine nouns of the first declension) it is, however, possible to determine the case where there is an accompanying adjective. In the statistical tables data on ' $п$ + locative plural' and 'na + undifferentiated dative/locative' are included for the sake of completeness.

All the evidence provided by our sources is compared with what one may reasonably take to be a recent authoritative statement by Soviet Byelorussian scholars on the subject of the case governed by the preposition na: the entry for that preposition in the third volume of Ttumačalny stoünik biełaruskaj movy (hereafter TSBM). ${ }^{15}$ 
1. Spatial relations

Table 1

па in constructions expressing spatial relations

Meaning

Construction

MZ

KC

IM

VA Total

1. 'up to'

sg./pl. + acc.

3

35

$7 \quad 11$

26

2. direction/location of action (with the nouns бок, старана, край, рука)

$$
\begin{aligned}
& \text { sg. + acc. } \\
& \text { sg. + loc. } \\
& \text { pl. + acc. } \\
& \text { pl. + loc. }
\end{aligned}
$$

3. 'along, over, across'

$\begin{array}{rrrrr}\overline{1} & 21 & 3 & - & 24 \\ \overline{3} & - & 1 & - & 1 \\ 9 & 6 & - & 9\end{array}$

4. confines of action

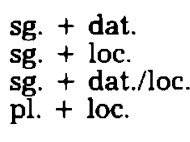

$\begin{array}{rrrr}\overline{10} & - & & 5 \\ 42 & 13 & 22 & 78 \\ 1 & 37 & 28 & 145 \\ 3 & 5 & 13\end{array}$

$$
\begin{aligned}
& \text { sg. + dat. } \\
& \text { sg. + loc. } \\
& \text { sg. + dat./loc. } \\
& \text { pl. + loc. }
\end{aligned}
$$

1

$\begin{array}{rrr}7 & & 10 \\ 13 & 10 & 79 \\ 24 & 13 & 77 \\ 23 & 7 & 95\end{array}$

5. following a route

$$
\begin{aligned}
& \text { sg. + dat. } \\
& \text { sg. + loc. } \\
& \text { sg. + dat./loc. } \\
& \text { pl. + loc. }
\end{aligned}
$$

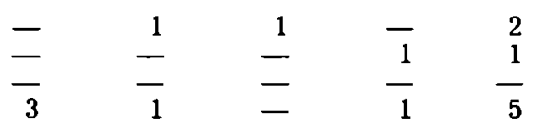

\subsection{Spatial limit ('up to')}

With this meaning na combines only with the accusative case (see Table 1) and this is also the sole construction shown in TSBM. Examples:

Ідзі барані «свабоду». . пакармі вошы, пасядзі па шъю ў вадзе, падстаў свой шчыры лоб пад нямецкую кулю (MZ); Незнаёмы 3 мясцовасцю чалавек у крынічышчах мог бы ўплыць na горла (КС̆); Адзін 3 іх вельмі рослы, здалёк відаць, другія два ледзь na плячо яму (IM); Шарая каламуць снегу засцілала мястэчка, замятаючы па вокны нізенькія атынкованыя хаткі (VA).

Cf. a corresponding construction in Russian (по пояс, по колени etc).

\subsection{Direction/location of action (with certain nouns)}

According to TSBM there are four nouns which can combine with na in the accusative case to express the direction or location of an action: бок, старана, край and рука. Our data involve exclusively the noun бок and are largely accounted for by Corny's predilection for the phrase па той бок (па гэты бок). There is also a clear contrast between singular and plural usage (see Table 1) with 'na + accusative' in all but one instance in the former, 'na + locative' in all but one instance in the latter. Examples: 
Скуратовіча уббачылі na гэты бок ельніку (КС̆); Яны ішлі $n a$ другі бок вуліцы (IM); Ніхто не прымеціў, як Карла... скакаў цяпер па тъцм баку - у напрамку пад станцыю (MZ); Сцежка прыгожая - на ёй мякенькі жоўты пясочак, а па баках свежыя кветкі (MZ); твань мокла толькі па бакаx (IM); Было 6 з ёй зусім добра, калі б па абодва бакі Ганны не ішлі хмурны, насцярожаны сусед Васіль. . . і - гаварлівы, упэўнены, нахабны Яўхім Глушак (IM).

In the corresponding construction in Russian no is combined with either the accusative or dative case (по ту сторону, по той стороне).

\subsection{Movement along/over/across}

Of the large number of examples of this construction provided by our sources (see Table 1) only five (fractionally over $2 \%$ ) indisputably involve the dative case. Perhaps significantly all five occur in MZ, the earliest of the sources; for present-day Byelorussian TSBM shows only the construction 'na + locative'. Examples:

with dative: Можа, там мітусяцца акраўкі калматыя хмар, у перагонкі гуляюць па чорнаму небу? (MZ); аж пакуль не перакуліўся ён на той бок і не пашыбаваў па полю ўслед за сваімі харобрымі таварышамі (MZ);

with locative: Па небе лёгка плылі беленькія пярэстыя балачьнкі (MZ); грымаса прайшіз ў не па тваръ (КС̆); дробныя крокі зноў застукалі па дварљ (КС̆); хадзіць па балоще даводзілася ўжо нямала (IM); Калі Яуххім праводзіў яе па загуменні (IM); Нехта шаркаў нагамі па гліняным тажу (VA); Па хляве мільгнуў і зліўся 3 поцемкам у кутках цень (VA).

\subsection{Confines of action}

Again, the number of examples of па combined with an indisputably dative form is small (see Table 1) - c. $4 \%$ of the total number of examples of this construction and only c. $11 \%$ of those singular forms which are clearly identifiable as dative or locative. None of these examples occurs in our most recent source (VA) and once again TSBM shows only the locative case. Examples:

with dative: і яна пайшла хадзіць na вакзалу і навокал яго (КС); Калі адзявауся, каб пахадзіць па марознаму вячэрняму двару (IM);

with locative: Хто сядзеў, хто стаяў, хто хадзіў па пакоі (MZ); Ідзе ад яе [дудкі] водгулле, па ўсім свече разносіцца, навучае людзей (MZ); увесь прамоклы ад дзённага вандравання па балоче (KС̆); я збіраю па иэлысм раёне уусе весткі (КС); Млосць расплывалася і $n a$ усім целе (ПМ); [яна] умее ганяць пярэпалахі, качаючы па жъьвце яйцом (VA).

1.5 Following a (usually predetermined or prescribed) route 
Here the number of examples in our sources (see Table 1) is too small to be statistically significant, but for what it is worth both dative and locative are found in the singular. TSBM has only the dative case (locative in the plural). Examples:

with dative: Трэба ісці ўперад і ўперад, па ленінскаму марируту (IM);

with locative: Але Алеся яго ўжо не чула, бегла па разарваным лажиужжу сваіх слядоў (VA).

2. Temporal relations

Table 2

na in constructions expressing temporal relations

$\begin{array}{llllllll}\text { Meaning } & \text { Construction } & \text { MZ } & \text { KC } & \text { IM } & \text { VA } & \text { Total }\end{array}$

1. 'after'

$\begin{array}{llllll}\text { sg. }+ \text { dat. } & - & - & 1 & - & 1 \\ \text { sg. + loc. } & 2 & 1 & - & 1 & 4 \\ \text { sg. + dat./loc. } & - & 1 & - & 3 & 4\end{array}$

2. expressing time of regular action

pl. + loc.

$-\quad-$

$2 \quad-\quad 2$

2.1 'After'

TSBM shows only 'na + locative' for this meaning, but our sources (see Table 2) did throw up one example of the dative singular:

- Дак якое ж цяпер дзяленне?! - крыкнуў Хоня. - Па такому снегу? (LM).

More usual is the locative:

Лясніцкі не па доўгім часе развітаўся і выйшаў (MZ); Адзін тэкінец кінуўся туды і па невялічхім часе прывалок да краю збянтэжанага басяка (MZ); Па поўдні Люба вынесла свайго сына на двор, на сонца (KC).

It must be said, however, that (as in 1.5) the number of examples is insufficient for any firm conclusions to be based on them.

\subsection{Time of regular action}

For both singular and plural TSBM has 'па + locative'; our sources contain only two examples with the noun in the plural (па начах 'at night(s)').

\subsection{Other}

There are two further types of temporal relationship expressed with the aid of the preposition na for which our sources provide no examples: temporal limit ('up to', 'until') for which, as with spatial limit, 'na + accusative' is the norm; and something not dissimilar to 2.2 - repeated but not necessarily regular action ('at a time') for which TSBM 
records the use of the dative singular as in, for example, не прыходзіць па тьдню, па цэламу месяцу.

\section{Objective relations}

Table 3

na in constructions expressing objective relations $\begin{array}{lllllll}\text { Meaning } & \text { Construction } & \text { MZ } & \text { KC } & \text { IM } & \text { VA } & \text { Total }\end{array}$

1. 'at, on, against'

$$
\begin{aligned}
& \text { sg. + dat. } \\
& \text { sg. + loc. } \\
& \text { sg. + dat./loc. } \\
& \text { pl. + loc. }
\end{aligned}
$$

2. with verbs of emotion

$$
\begin{aligned}
& \text { sg. + dat. } \\
& \text { sg. + loc. } \\
& \text { sg. + dat./loc. } \\
& \text { pl. + loc. }
\end{aligned}
$$

$\begin{array}{rrrrr}2 & 1 & - & & 3 \\ 14 & 10 & 11 & 27 & 62 \\ 5 & 20 & 18 & 30 & 73 \\ 4 & 5 & 8 & 19 & 36\end{array}$

3. type, sphere of action

$$
\begin{aligned}
& \text { sg. + dat. } \\
& \text { sg. + loc. } \\
& \text { sg. + dat./loc. } \\
& \text { pl. + loc. }
\end{aligned}
$$

$\begin{array}{rrrrr}-3 & 1 & - & - & 1 \\ 1 & 3 & 5 & - & 11 \\ 1 & 7 & 8 & 2 & 18 \\ & 1 & - & - & 2\end{array}$

4. 'according to, in accordance with'

$$
\begin{aligned}
& \text { sg. + dat. } \\
& \text { sg. + loc. } \\
& \text { sg. + dat./loc. } \\
& \text { pl. + loc. }
\end{aligned}
$$

$\begin{array}{rrrrr}3 & - & 5 & - & 8 \\ 10 & -3 & -8 & -1 & \frac{22}{-}\end{array}$

5. basis of action ('by, from')

$$
\begin{aligned}
& \text { sg. + dat. } \\
& \text { sg. + loc. } \\
& \text { sg. + dat./loc. } \\
& \text { pl. + loc. }
\end{aligned}
$$

$\begin{array}{rrrrr}7 & - & 20 & 1 & 28 \\ 3 & - & -1 & -1 & 3 \\ 20 & 10 & 22 & 1 & 53 \\ 7 & 1 & 1 & 1 & 10\end{array}$

3.1 Action aimed at object ('at, on, against')

Here TSBM has 'na + locative' without qualification and the overwhelming majority of examples from our sources (see Table 3 ) support this. There are three isolated instances of 'па + dative' in the earlier works:

але рабочы, мабыць, не зразумеўшы гэтага, здзеў яму шапку лёгкім ударам далоні па цемю (MZ); I выразна, гулка пстрыкае сябе па горлу (MZ); Вэня ляпнуў сабе па калену (КС̆).

Examples with the locative (singular):

Апавядальніка перабіў зноў той п'яны, вьщяўшы зноў кулаком па стале (MZ); Андрэй ударыў сябе па ілбе (MZ); Той бесперапьнна біў Тварыцкага па твары $i$ галаве (КС̈); na зайчъкавъцм кажусе запляскалі кулакі (IM); Папацала лісце на дубку, і выдавала, што па іл сячэ дробны дождж (VA); чы пнём па саве, чы савою па nнi, - то саве бяда (VA); ён адкруціў з вазовай ручкі канец сырамятных лейщаў, шлёгнуў імі па кані (VA). 


\subsection{With verbs of emotion}

Verbs expressing sadness or longing such as бедаваць, плакаць, сумаваць, тужыць etc. (and nouns associated with them e.g. сум, туга) are followed by na and the object of these emotions. TSBM indicates ' $\mathrm{ma}+$ locative' but adds the rider 'but also with the dative in the singular'. Our sources show an overwhelming preference for the locative case (see Table 3), with a single indisputably dative example:

Быў у лісце і сум па старьгх бацьках і па дому (КС̆).

Examples with the locative (singular) include:

як ціхі сум па мінульм (MZ); А яна яшчэ па сыне ныла, што на вайне недзе (КС̆); Ваша месца па вас сумуе, даўно не былі (KČ); усе зразумелі, кім захапляецца і па кім журыцца (IM).

\subsection{Type, sphere of action}

This is the semantic area in which 'no + dative' has become so aggressive a construction in modern Russian (see fn.5) and it appears that the same may well be true of modern Byelorussian, for not only does $T S B M$ show only 'nа + dative' in the singular, but also of the thirty examples in our sources (see Table 3), in not one instance is the construction 'nа + locative' found. Some examples:

Па першаму пытанню рабіў даклад невысокі тонкі хлопец (MZ); Па пісъму я самы першы ў класе (IM); слова мае старшыня камісіі па землеўпараджаванню Дзяцел Міканор (IM).

\section{4 'According to, in accordance with'}

As with 3.3 TSBM shows only 'na + dative' for the singular and the evidence of our sources (see Table 3 ) is substantially in agreement. Only the earliest (MZ) has occasional examples with the locative case:

можна знайсці сапраўдны старадаўні план, па якім выходзіць, што лука належыць да сялянскай зямлі, а не да панскай; Разнапёрыя па сваім асабовым складзе..., гэтыя атрады выяўлялі сабой сапраўды непаўторную карціну.

Examples with the dative case:

Тут дзела яснае: сяляне касілі луку па праву (MZ); а Халіма па свайму улююблёнаму звычаю размашыста курыў (MZ); Васіль у доме станавіўся як бы старэйшым па чыну (IM); Хадоська, дастаючы па Міканораваму загаду чыстую латку, божкала (IM); Мы, не сакрэт, усё праверым і зробім па закону! (IM); Па верасаўскаму звычаю не знімаючы з галавы шапкі у чужой хаце (VA).

\subsection{Basis of action ('by, from')}

TSBM indicates 'na + locative' as the norm but, as with 3.2 , adds the rider 'but also with the dative in the singular'. Our sources give a fair 
reflection of this, splitting $3: 1$ in favour of the locative case in the singular (see Table 3). Examples:

with dative: Па тону яго голасу ніяк няможна было падумащь, што гэта ён гаворыць пра сябе (MZ); усе па яго выгляду маглі бачыць, як іх пакрьг̆дзілі (IM);

with locative: я чую na дъие, што нейкі дзіўны тытунь (КС̆); потым па шчаслівым Васілёвым твары, па гаворках жанчын [маці] зразумела ўсё (IM); Ганна. . na голасе яго згадалася, што было $з$ ім (ММ); Па тымм, як прамовіў сьн, ... стары Глушак усё зразумеў (IM); Яна пазнала яго... па цёмным, накінутым наапашкі пінжаку (VA).

\subsection{Means of action}

Our sources have no examples of such constructions as вьвучаць па сваім падручніку, ісці па компасу, перадаваць па радыё, for which TSBM has 'na + locative' as the recommended norm, but allows also 'па + dative' in the singular (cf. $3.2,3.5$ ).

\section{Distributive relations}

Table 4

na in constructions expressing distributive relations

$\begin{array}{llllll}\text { Construction } & \text { MZ } & \text { KC } & \text { IM } & \text { VA } & \text { Total }\end{array}$

1. with nouns

$$
\begin{aligned}
& \text { sg. + dat. } \\
& \text { sg. + loc. } \\
& \text { sg. + dat./loc. } \\
& \text { pl. + loc. }
\end{aligned}
$$

MZ KC

IM

VA Total

2. with the numeral 'one'

$$
\begin{aligned}
& \text { sg. + dat. } \\
& \text { sg. + loc. } \\
& \text { sg. + dat./loc. }
\end{aligned}
$$

$\begin{array}{lll}\overline{3} & \overline{4} & =\end{array}$

3. with the numerals 'two

and upwards'

$$
\text { pl. + acc. }
$$

$\begin{array}{rrrrr}-3 & - & - & - & - \\ - & - & - & 1 & 1\end{array}$

\subsection{With nouns (including numeral-nouns)}

$T S B M$ has only 'na + dative' for the singular. The evidence of our sources is inconclusive, since all the examples of this construction which occur (see Table 4) involve nouns which do not formally distinguish the dative and locative singular, e.g.:

і уусе ўтраіх выпілі дружна па чариъ (MZ); Над двума дзвярыма вісела па карціне у рамах і за шклом (КС); - А што-така ўжо такое, калі мужчьпы па кілішку вып'юць? (VA).

\subsection{With the numeral 'one'}

Here TSBM gives equal weight to 'па + dative' and 'na + locative'. 
Our sources, however, show a strong preference for the latter construction and contain only one example which is capable of being interpreted as a dative form (see Table 4). Examples:

with locative: Ён пачаў гаварыц гучна і мерна, выкідаючы na адным 3 сваіх магутных грудзей важкія шурпатыя словы (MZ); Несцяровіч гэтак спакойна пісаў даведку, па аднъм слове паміж глыткамі чаю (КС̆); зноў збіраліся мужчьны, па адным адлучаючыся ад купкі (VA);

with dative/locative: калі яны [жанчыны] увайшлі ў вёску і $n a$ адной адлучаліся ад купы (VA).

\subsection{With the numerals 'two and upwards'}

The sole construction is 'na + accusative', both in the examples which occur in our sources (see Table 4) and according to TSBM. TSBM adds that even where animate nouns are involved the form of the accusative case is usually that which is identical with the nominative, though accusative $=$ genitive is 'also permitted'. Examples:

пастроілі па два чалавекі ў рад (MZ); Карціны местачковага ужытку, па капеек чатыры кожная ў даваенны час (КС̆); няслі, трымаючы спадыспаду рукамі, па два пляскатыя мяхі (VA).

\section{Quantitative relations}

Table 5

па in constructions expressing quantitative relations

$\begin{array}{llllll}\text { Construction } & \text { MZ } & \text { KČ } & \text { IM } & \text { VA } & \text { Total }\end{array}$

1. with nouns

$$
\begin{aligned}
& \text { sg. + dat. } \\
& \text { sg. + loc. } \\
& \text { sg. + dat./loc. } \\
& \text { pl. + loc. }
\end{aligned}
$$

MZ

2. with the numerals 'two

and upwards'

$$
\text { pl. + acc. }
$$

3

$\begin{array}{lll}\overline{1} & = \\ - & =\end{array}$

$\begin{array}{lll}1 & - & 1 \\ - & - & 1\end{array}$

\subsection{With nouns}

For the singular TSBM indicates 'па + dative'. Our sources contain no examples which are indisputably locative (see Table 5), but since there are only two in all, this is not conclusive:

with dative: Ну і унцер: кулакі na nyдy! (VA);

with dative/locative: ён аддаў мне вас па тысячъ марак за чалавека (MZ).

\subsection{With the numerals 'two and upwards'}

As in 4.3, the sole construction is 'na + accusative', both in the examples from our sources (see Table 5) and according to TSBM. Examples:

хлопцам было па якіх дваццаць ці меней гадоў (MZ); і у кожнай 
хаце па сорак два акны ў сцяне і па чацвёра дзвярэй (КС); Грэбля гэтая звязвае Курані, якія па паўгода, можна сказаць, былі адрэзаны ад другіх сёл, 3 Алешнікамі, 3 Юравічамі, са ўсім светам (IM); На варту ў Верасаве вьходзілі па дзве хаты засаб (VA).

6. Relations of manner

Table 6

na in constructions expressing relations of manner

$\begin{array}{llllll}\text { Construction } & \text { MZ } & \text { KC } & \text { IM } & \text { VA } & \text { Total }\end{array}$

adverbial, involving abstract nouns

$\begin{array}{llllll}\text { sg. + dat. } & - & - & - & - & - \\ \text { sg. + loc. } & - & - & - & - & \overline{19} \\ \text { sg. + dat./loc. } & 10 & 2 & - & - & -\end{array}$

TSBM indicates ' $\mathrm{na}+$ dative' for the singular. All the examples from our sources (see Table 6) are ambiguous, perhaps unsurprisingly so, since it is almost exclusively abstract nouns which are involved in this particular semantic relationship and the majority of these are, of course, feminine in Byelorussian. Some examples:

Колькі хвілін Лясніцкі і па праўдзе чытаў, нават разумеў прачытанае (MZ); я раскажу ўсё па параджу (MZ); Яшчэ пагавару 3 ім па шиырасці (КС̆); Парадкі цяпер такія, што могуць перадзяліць па справядлівасці (IM); Услед за ім ужо задам і, мусіць, па добрай волі вываліўся Рысек Пясэцкі (VA).

\section{Causative relations}

Table 7

па in constructions expressing causative relations

$\begin{array}{lllllll}\begin{array}{l}\text { Meaning } \\ \text { 'out of, because of' }\end{array} & \begin{array}{l}\text { Construction } \\ \text { sg. + dat. }\end{array} & \text { MZ } & \text { KC } & \text { IM } & \text { VA } & \text { Total } \\ & \begin{array}{l}\text { sg. + loc. } \\ \text { sg. + dat./loc. }\end{array} & - & - & - & - & - \\ \text { pl. + loc. } & -1 & - & - & 2 & 2 \\ & & - & - & 2 & - & 2\end{array}$

7.

For the singular TSBM has only 'nа + dative'. By contrast our sources (see Table 7) contain only examples of 'па + locative' or 'па + dative/ locative', though (as in 1.5 and 5.1) the total number of examples is perhaps too small to be statistically significant. They include:

with locative: Змаўляліся не толькі па суседстве ці па сваяцтве (VA);

with dative/locative: але na mой прычыне, што ён не прыехаў, зноў буду гаварыць я (ПМ). 


\section{Purposive relations}

Table 8

na in constructions expressing purposive relations

$\begin{array}{lcrrrrr}\begin{array}{l}\text { Meaning } \\ \text { 'for, to get }=\text { to fetch' }\end{array} & \text { MZ } & \text { KC } & \text { IM } & \text { VA } & \text { Total } \\ \text { sg. + acc. } & - & 11 & 4 & 9 & 24 \\ \text { pl. + acc. } & - & 4 & 4 & - & 8\end{array}$

To express purpose ('to get $=$ to fetch', usually after verbs of motion) па combines solely with the accusative case (see Table 8) and this is the only construction shown in TSBM. Examples:

- Чыя чарга сёння па хлеб ісці? (KС̈); У такіх выпадках прыязджалі сюды пa гонту здалёк (КС); ШПпарка збегала яна у яслі па съна (КС); Пад раніцу бацька запрог каня, паехаў па доктара ў Загалле (IM); - Можа, па ксяндза трэба было б з'ездзіць? (VA); Ен, гэты Статкевіч, паслаў мяне ў Слонім па лякарства (VA).

What conclusions, then, may be drawn about the combination of the preposition na with the accusative, dative and locative cases in modern Byelorussian? How does the situation compare with that in modern Russian?

First of all, it can be seen that where the construction 'па + accusative' is concerned usage is straightforward and easily definable. In modern Byelorussian 'nа + accusative' has the following functions:

(a) to express a spatial or temporal limit (1.1);

(b) to express purpose, principally after verbs of motion (8);

(c) in quantitative and distributive constructions where the preposition governs a numeral other than 'one' $(4.3,5.2)$;

(d) to express the direction or location of an action with certain nouns (бок, старана, край, рука) (1.2).

Only in the case of (d) is there the possibility of an alternative construction involving the preposition па (+ locative).

The use of 'na + accusative' to express a spatial or temporal limit and to express the direction or location of an action with a limited number of nouns is shared by Russian (cf. BR па калена, па той бок - $\mathrm{R}$ по колено, по ту сторону etc.). This is also largely true of quantitative and distributive expressions in which the preposition governs a numeral other than 'one', but whereas in Byelorussian usage is entirely consistent, that of Russian is, as yet, less firmly established. Russian grammars continue to recommend a division between 'no + accusative' with the numerals 2, 3, 4 (and compounds of these), 200, 300,400 (and composite numerals beginning with these) on the one hand, and 'no + dative' with all other numerals. Spoken and journalistic practice belies this, however, with 'no + accusative' 
predominating heavily over the older construction 'no + dative' in the latter group, ${ }^{16}$ an instance of Russian moving closer to the Byelorussian position rather than vice versa. The Byelorussian purposive construction 'na + accusative' = 'for, to fetch, to get' is found in Russian only in dialect usage; standard Russian has ' $3 a$ + instrumental'.

Secondly, though we have come a long way from Taraškievic's Bietaruskaja hramatyka dla škot, which did not even admit the possibility of combining na with the dative case in Byelorussian, ${ }^{17}$ and though examples of 'na + dative' are to be found in our sources for all the semantic constructions expressing objective relations and all but one (that of spatial limit) expressing spatial relations, there are only two in which it clearly predominates over 'па + locative': in the expression of the type or sphere of action (3.3) and with the meaning 'according to, in accordance with' (3.4) ${ }^{18}$ It is significant, however, that both these semantic categories are ones in which 'nо + dative' has been particularly aggressive towards other constructions in modern Russian, as was noted above. They are also the two major categories for which TSBM unequivocally indicates the use of 'па + dative' in the singular. What we appear to be seeing is a parallel development in Byelorussian and the fact that both constructions are especially characteristic of the journalistic, technical and scientific styles of the language, in which the influence of Russian is most strongly felt, would tend to confirm this. Thus, in a recent book on linguistics (reviewed in the previous issue of The Journal of Byelorussian Studies) ${ }^{19}$ among a total of 102 such constructions not a single one has an indisputably locative form (63 show 'па + dative', 39 'па + dative/locative'). What we are dealing with here, though, is not so much a switch from 'na + locative' to 'na + dative' but, as in Russian, the ousting of other prepositional constructions, for example, 'па + dative' in place of 'паводле + genitive' in the sense of 'according to, in accordance with'. ${ }^{20}$

Elsewhere the use of the dative case remains, for the present at least, generally marginal. Thus, in all constructions expressing spatial relations (leaving aside spatial limit which is conveyed by 'na + accusative') 'па + dative' accounts for only 17 out of 422 examples encountered in our sources (just over $4 \%$ of the total); moreover, not one of these occurs in our most recent source (VA). In constructions denoting objective relations, other than the two discussed in the preceding paragraph, 'na + dative' is similarly sparsely represented; in this case 11 times out of 208 (a little over $5 \%$ ). Nevertheless, the situation does appear to be changing: TSBM gives 'na + dative' in quite a number of semantic constructions either as an alternative to 'na + locative' (see $3.2,3.5$ above) or as the sole (singular) form (see 1.5, 3.3, 3.4, 4.1, 5.1, 6, 7 above). Interesting, if semantically not very discriminating, light is thrown on this development by the two editions of M.S. Jaunnievic and P.U. Ściacko's Sintaksis sučasnaj biełaruskaj movy. In the first (1969) edition it is stated that in Byelorussian with the aid of the preposition па verbs and nouns denoting actions (as opposed to feelings) 'govern the locative case of a noun both in the plural and in the singular' (my 
italics - PJM), ${ }^{21}$ but in the second (1980) edition this has become 'govern the locative case of nouns in the plural' (my italics - PJM). ${ }^{22}$

Finally, the question arises as to how far the use of 'na + dative' can be put down to the influence of Russian and how far it may represent a specifically Byelorussian development. It would, of course, be unreasonable to deny altogether the influence of Russian on Byelorussian in this as in so many other areas and, as was mentioned above, this is particularly true of the journalistic, technical and scientific styles of the language. In this connection it is interesting to note that P.P. Suba, in his book on the preposition in Byelorussian, sees the use of 'na + dative' as very much a 'borrowing', confined predominantly to these styles. $^{23}$ There is, however, one big question mark remaining against the thesis that the use of 'na + dative' is entirely the result of Russification: if that is the case, why has it affected only the singular? After all, Russian does not discriminate between singular and plural in the way that Byelorussian does in this area; indeed, so far as one can ascertain, in the Slavonic languages as a whole there is no evidence of any preposition in the same semantic construction governing different cases in singular and plural. It seems likely, therefore, that while Russian has clearly had a role in this development, at least part of the reason for the spread of 'па + dative' at the expense of 'па + locative' may be found in the frequent coincidence of form between the two cases in the singular, giving rise to morphological analogy. This would certainly help to explain the discrepancy between the singular and the plural. It is even not inconceivable that, as has happened with the nominative/accusative plural of neuter nouns (vis-à-vis masculine and feminine) and to a considerable degree with the genitive plural of feminine and neuter nouns (vis-à-vis masculine), the forces of analogy could eventually lead to a situation in which dative and locative singular cease to be formally distinguished at all in Byelorussian.

\section{NOTES}

1. See V.N. Toporov, Lokativ v slavjanskix jazykax, Moscow, 1961, pp. 328-31.

2. ibid., pp.275-85.

3. ibid., pp.336-40.

4. ibid., p.332.

5. See N. Ju. Švedova, Aktivnye processy $v$ sovremennom russkom sintaksise, Moscow, 1966, pp.40-52. Švedova gives examples of 'no + dative' vying with the following syntactic constructions: adjectival (футбольная команда/ команда по футболу); prepositionless genitive (план выпуска/ план по выпуску); prepositional (книга о шахматах/по шахматам, автоматы для продажи/по продаже молока, первое место в производстве/по производству, конкурс на скорость/по скорости печатания, пятерка за поведение/по поведению еtc.). The continuing aggressiveness of 'по + dative' towards other constructions in modern Russian is confirmed by L.K. Graudina et al. (Grammatičeskaja pravil'nost' russkoj reči. Opyt častctno-stilističeskogo slovarja variantov, Moscow, 1976, pp.42-45).

6. Toporov, op.cit., p.61. 
7. T. Wade, Prepositions in Modern Russian, Durham Modern Languages Series, 1983.

8. V.S. Bondarenko, Predlogi v sovremennom russkom jazyke, Moscow, 1961, p.29.

9. ibid., p.30.

10. ibid.

11. Graudina et al., op.cit., pp.48-49.

12. These include: Hramatyka bietaruskaj movy. 1. Marfatohija, Minsk, 1962, pp. 459-60; 2. Sintaksis, Minsk, 1966, pp.59-61, 88-90, 193-94, 226-27; H.D. Zyłunovic, 'Niekatoryja vypadki razychodžańnia ù kiravańni biełaruskich uskosnapierachodnych dziejasłovaŭ i ich ruskich adpaviednikaŭ', Vieści AN BSSR. Seryja hramadskich navuk, 3, 1965, pp.108-17; A.N. Naumovič, 'Imennye slovosočetanija s predlogom po (pa) v vostocnoslavjanskix jazykax', in Materialy naučno-teoreticeskoj konferencii. Tezisy dokladov, Minsk, 1965, pp.318-24; id., 'Konstrukcii s predlogom po v vostočnoslavjanskix jazykax, vyražajušcie ob"ektnye otnošenija', in Issledovanija po russkomu jazyku, Minsk, 1965, pp.72-109; id., 'Niekatoryja asablivaści słovazłučeńniaŭ z prynazoŭnikam po ŭ ruskaj i $p a$ ŭ biełaruskaj movach', Narodnaja aśvieta, 11, 1965, pp.27-33; L.P. Padhajski, Stovaztučńnnie ù biełaruskaj movie, Minsk, 1971, pp.46-50, 94-97, 126-28; U.C. Piskun, V.I. Rahaŭcoŭ, 'Sinanimičnyja prynazoŭnikavyja ekvivalenty kanstrukcyj "pa + peŭny skłon» u sučasnaj biełaruskaj litaraturnaj movie', Biełaruskaja mova i movaznaŭstva, 1, 1973, pp.127-36; Sučasnaja bielaruskaja litaraturnaja mova. Marfałohija (pad red. F.M. Jankoŭskaha), Minsk, 1975, pp.22833; P.P Śuba, 'Prynazoŭnik pa ŭ biełaruskaj movie', in $Z$ zyćcia rodnaha stova, Minsk, 1968, pp.80-87; id., Prynazoŭnik u bietaruskaj movie, Minsk, 1971, pp.59-75; M.S. Jaŭnievič, 'Niekatoryja paraleli va ŭžyvańni prynazoūnikavych kanstrukcyj u biełaruskaj i ruskaj movach', Pracy Instytuta movaznaǔstva imia Ja. Kotasa AN BSSR, VI, 1959, pp.221-35; id., 'Užyvańnie prynazoŭnika $p a$ ŭ suČasnaj biełaruskaj litaraturnaj movie', in Linhvistyčny zbornik, Minsk, 1965, pp.212-41.

13. We did, in fact, encounter one instance of na + dative plural, but only in dialogue, in the non-standard speech of one of the characters in Mielež's novel Ludzi na batocie: - У нас таксамо камісія, якая була выбрана na ўсім законам на агульным сходзе вёскі Курані, знайшла розныя факты. А іменна - няправільную запісь зямлі сельсавету, што прывяло ў сваю чаргу да няправільнай аплаты налогу 3 боку етьх укрывацеляў.

14. Some scholars would assign the locative ending $-y(-\wp)$ to other categories of second declension masculine nouns (see P.J. Mayo, 'Recent developments in the norms of the Byelorussian literary language', JBS, III, 3, 1975, pp.253-57, thereby eradicating formal differentiation between dative and locative, but the two categories mentioned are the only ones on which there is general agreement.

15. Ttumačalny stoŭnik biełaruskaj movy, vol. 3, Minsk, 1979, pp.448-50.

16. See Graudina et al., op.cit., p.47.

17. B. Taraškievič, Bielaruskaja hramatyka dla skot, 5th edn, Vilna, 1929, p.106. The only preposition he shows as governing the dative case is $\mathbf{k}$, and even then he adds the rider that more common is 'да + genitive'.

18. In a third construction, with the spatial meaning of 'following a route' (1.5), there is a count of 2-1 in favour of the dative. Though the number of exam- 
ples is too small to have any real significance, it is interesting that this construction, while in one sense undoubtedly conveying spatial meaning, at the same time comes close to the objective construction 'according to, in accordance with', particularly in such figurative examples as: Трэба ісці ўперад і ўперад, па ленінскаму маршруту (IM).

19. A. Ja. Bachańkoū, Razvićcio leksiki biełaruskaj litaraturnaj movy ù saviecki pieryjad, Minsk, 1982 (231 pp.).

20. See Piskun and Rahaŭcoŭ, op.cit., pp.131-32.

21. M.S. Jaŭnievið̌, P.U. Ściacko, Sintaksis sučasnaj biełaruskaj movy, Minsk, 1969, p.16.

22. ibid., 2nd edn, Minsk, 1980, p.16.

23. Šuba, Prynazoūnik u biełaruskaj movie, p.75. 